\title{
Strengthening National Character by Reconciliation the Testament: Local Literature in the Post-National Era
}

\begin{abstract}
Khirjan Nahdi ${ }^{1}$, Dukha Yunitasari ${ }^{2}$, Suhartiwi $^{3}$, Atiaturahmaniah ${ }^{4}$, Doni Septu Marsa Ibrahim ${ }^{5}$
Universitas Hamzanwadi ${ }^{1,2,3,4 \& 5}$, Indonesia

Correspondence: Khirjan Nahdi, Universitas Hamzanwadi. Indonesia, e-mail: khirjan.nw @gmail.com

Submitted: April 04, 2020

Revised: April 23, 2020

Accepted: April 25, 2020

DOI: $10.29408 /$ veles.v4i1.2011

URL: http://dx.doi.org/10.29408/veles.v4i1.2011

Abstract

This study aims to find the value of nationality in Hamzanwadi's testament. Hamzanwadi is a local figure in Lombok with global outlook. Testament in the form of rhymes and poetry contain national values; need to be strengthened in the post-national era. The testament understood through the dialectical and hermeneutic methods. Through dialectics and hermeneutics, it is understood that the value of Indonesian nationality regarding Pancasila, the 1945 Constitution, the Republic of Indonesia, and Unity in Diversity. National presence of the four national values is illustrated through the birth of religiousism, faith, piety, justice and prosperity. The results of the discussion focused on the nationality recommended of the post-national era through the transfer of knowledge, strengthening of values, value implementation by all parties and all institutions.
\end{abstract}

Keywords: National character, testament, local literature, post-national

\section{Introduction}

The national character in the Indonesian context is understood as an individual and collective awareness of the nation regarding independence, ideology, welfare, unity, culture, and other aspects of intelligence that originate from the four pillars of nationality. (Muladi, 2019). The four pillars of nationalism are Pancasila, the 1945 Constitution, the Unitary State of the Republic of Indonesia and Unity in Diversity. Today, the national character as the basis for national action experiences various challenges. Challenges occur in the form of denial of basic human rights and humanity; strengthen individual identity and deny diversity; and the tendency to control resources individually by ignoring mass interests. Gradually, these challenges will interfere with the ideals of educating the nation's life as mandated by the 1945 Constitution. As an element of the nation who is aware of this condition, it is impossible to dissolve in these contextual conditions by simply lamenting without proactively restoring awareness and collective action in restore the state of filling and continuing the noble ideals of the intellectual life of the nation. The strategic thing to do is to strengthen national character through local literary works in the postnational era.

The intended local literary work is the testament of a local figure in West Nusa Tenggara (abbreviated NTB), in the form of old literature, and has a national dimension. Testament was 
created by a National Hero from NTB, Mr. Kyai Haji Muhammad Zainuddin Abdul Madjid or Hamzanwadi. Testament contains a narrative of strengthening individual and collective awareness in the nation and state by upholding the values of the Pancasila, the 1945 Constitution, the Republic of Indonesia, and Unity in Diversity. Testament was born as a local treasure which has a national dimension in building the national character of Indonesia. In the condition of nationality today, the post-national generation of Indonesia is very important to refer to the national values that are expressed and implied in it. As reference material, understanding is needed, then it is used as a reference for the transformation of national values in strengthening the national character of Indonesia. Ter-Minasova (2015); Tolenovna \& Sabyrbaevna (2014) and Samal, Dinara, Tursun, \& Ibekeeva, (2014) proving this kind of strategy proved strategic in building a national mentality in building national character after the upheaval. The important objectives of this study are: first, to find the value of nationality in a testament that is important to be understood again and strategically used as a reference for the development of national character. Secondly, finding a strategic agenda for strengthening the value of Indonesian nationality, which originates from a testament in the current post-national era and beyond. This study has a strategic contribution in restoring national awareness derived from the local treasury as an instrument supporting the same agenda through official state documents that are structural in nature.

\section{Hamzanwadi and Testament}

Hamzanwadi stands for the name Hajji Muhammad Zainduddin Abdul Madjid Diniyah Islamiyah. This long name refers to the name of himself after performing the pilgrimage, family, and Hamzanwadi's gait in driving the development of Islamic diversity. Education was pursued in Mecca Ashaulatiyah Madrasah until 1933. Returning from Mecca, Hamzanwadi began normalizing Madrasa education curriculum, and in its peak in 1937 founded the Nahdlatul Wathan Madrasah (homeland movement) - Diniyah Islamiyah, a school for men, abbreviated as NWDI. Success of NWDI, Hamzanwadi founded the Madrasah Nahdlatul Banat Diniyah Islamiyah, abbreviated as NBDI, a school for women in 1943. Nahdi (2013); Fogg (2019) Revealed, in addition to establishing and fostering two Madrassas, in 1953 founded a mass Islamic organization, with the same name as the Madrasah, Nahdlatul Wathan. Through Madrasah and Nahdlatul Wathan organizations, Hamzanwadi initiated the ideals of independence, since before independence, and community development agendas after Indonesian Independence. In addition to the field of education and Islamic mass organizations, Hamzanwadi is also active in 1950-1960 In 1950-1960 he became a member of the constitutional assembly representing the Masyumi 1972-1982 In 1972-1982 he became a member of the People's Consultative Assembly (MPR) representing the Work Agendas (Golkar). Agendas for developing education, religion, socio-economics, society, and kyai'), were kyai'), and kyai'), to kyai'), developed kyai'), Hamzanwadi's kyai'), Hajji kyai'), Zainul kyai'), known kyai'), Tuan kyai'), Bajang kyai'), 'young kyai'), since Hamzanwadi died in 1997.

Testament in this study is an old literary work in the form of poetry and poetry, by Hamzanwadi. Fattah, dkk. (2017) notes, testament is a work that was born together with Hamzanwadi's work in the struggle for education, social, religious, and nationality. In terms of content, a testament contains a message and a moral urge to take part and continue to do the best 
for the sake of religion, society, homeland and nation. Kutha Ratna (2009) said, old literary works in the view of cultural studies are no less rich with historical content. Thus, old literary works such as testament can be a complement to the instruments of socialization, dissemination and education of national characters in the post-national era. We can read Ananta Toer's works on nationalism and imagined communities, as Hun (1971) described. It is so important that the same language and social organization which embody the national movement.

\section{Testament and National Character of the Post-National Era.}

Through the study of literary texts according to semiotics A. Sayuti (2000) stated, literary texts not only have a relationship with life, but also represent life in various forms of context. As a representation of life in historical context, literary texts, including the testament represent national characters in the cross-border of history from national to post-national times. As a local literary text, the testament reflects the social life, religion, culture, nationality and history of Indonesia. Referring Hofsetede, Rosa, Salvetti, Bertagni, \& Angeli (2010); Mennell (2015) states, the need for representation of Indonesia as a nation-state, a testament in line with globaluniversal dynamics in national to post-national contexts. Heryanto (2019); Anderson (1998) emphasized, nationalism must be translated, understood, and developed towards idealization, expansion of aspects, and inclusiveness across national borders as a more universal and global common project. Thus, an ideal, broad, inclusive and global context of nationalism was obtained in fulfilling a shared universality, known as post-national. Post-nationalism is an idealism and agenda of nationalism in the context of the nation-state that accommodates universal needs in the borders of the nation-state. Post-national ideas and agendas are inseparable from the problem of global, which has a wide influence on changing perspectives on democracy, justice, freedom to manage resources independently, and principles of equality. Sarmela (2015) call it a global society with the complexity of relations and cause changes in cultural structure and global economic trends. Such conditions often lead to the neglect of the national context as a context of development and prosperity. Nahdi, (2014) call it an abandoned historical legacy. In such conditions, the re-presence of old literary texts such as testament will be strategic as an instrument of reminder, reinforcement, and reference to national character.

\section{Method}

This study uses the literary sociology paradigm, as pointed out by Ritzer, Goodman (2008) with the assumption that testaments as literary texts are understood in the context of past, present, and future social contexts. Data were collected by documentation techniques through the grouping of testament text according to the purpose of the study. Data analysis using the dialectical method as carried out by Hauser (1985) was assisted by Versehen in the Gadamer hermeneutic tradition (Darmaji, 2014). Testament texts are understood as these and find the antithesis in today's dynamics. Through thesis and antithesis, the ideal synthesis of testament text is described as a reference for socialization, dissemination, and education of the national character of the post-national era.

\section{Findings}


Data is compiled from a testament titled: The Testament of the New Experience Period, published Hamzanwadi. Testament is published first in 1970, included in the code Period group, with code I. The second issue in 1981, included in the New Experiences group, with code II. The total testament consists of 443 stanzas, 233 stanzas group I (Devotional Period); 122 couplets group II (New Experience 1); and 88 group III verses (Devotional Period 2) (Source: Testament of the New Experiment Period, by Hamzanwadi, 1970). From all strophes, the analysis data amounted to 7 strophes, from the group I and group II.

\title{
3.1 Testament and National Character (Dialectics of Thesis, Antithesis, and Synthesis)
}

\author{
1/I: “...Negara kita berpancasila \\ Berketuhanan Yang Maha Esa \\ Ummat Islam paling setia \\ Tegakkan sila paling utama \\ 1/I: “...Our country is successful \\ Godhead \\ The most loyal Muslims \\ Keep the most important precepts.
}

As a thesis, the testament of bait no. 1 / I show the totality of consciousness as a nation that must uphold the divine value in the first precept of Pancasila. Geographically, this stanza appears in the local context of Lombok, West Nusa Tenggara, while the nation in question is Indonesia. The national awareness thesis that recognizes Pancasila was born as a social and historical responsibility, that spiritual life with a belief in God Almighty is a non-negotiable belief. The choice of the process and form of rituals and religious instruments becomes the basic rights of each citizen of the nation. God and religious narratives in Pancasila contain normative teachings and values according to the respective religious provisions. All normative teachings and values derived from the religion guide towards goodness. The antithesis is in the form of resistance to the truth of the thesis in verse 1 so that not all citizens of the nation obey the teachings and normative values of religion. In fact, there are still actions and actions that go against the construction of consciousness and the national agenda. Efforts are needed to strengthen the understanding and deity of God, which originates from Pancasila as a new thesis (synthesis) which confirms the position of the Almighty God as the first principle of Pancasila.
2/I: Hidupkan iman hidupkan taqwa
Agar hiduplah semua jiwa
Cinta teguh pada agama
Cinta kokoh pada Negara
2 / I: Turn on faith turn on taqwa
In order to live all souls
Solid love for religion
Solid love for the country

The thesis in verse 2 / I confirm the existence of religion that teaches faith and devotion as important as the existence of the state. If religion is a source of virtue, the state is a container to cultivate the virtue. Therefore, this thesis verse 2 teaches that the struggle to uphold religion is as important as the struggle to uphold the foundations of the state. In his journey, there was an 
antithesis that the alignment of this thesis did not face challenges, including the challenges of the nation's citizens. The challenge is in the form of rejection of religious plurality, and offering a single teaching religion as a single majority in the nation-state context. For the future of a civilization that upholds national values that recognize differences, new rationality is needed as a synthesis that offers new thoughts and agendas that value differences. Because the history of Indonesian nationality was born from various differences, including differences in religious beliefs.

3/I: Sasak yang tulen Nasionalisnya

Selalu dituduh sukuisme-nya

Sungguh penuduhlah sukuisme buta

Penuh buktinya di sini di sana

\section{3 /I: The true nationalist Sasak}

Always accused of its ethnicism

Really accusing blind ethnicism

Full of proof here and there

Verse 3/I contain the meaning of clarification to all children of the nation on the stigma that Sasak ethnicity is ethnic who prioritizes ethnic aspects. This stanza actually became the antithesis of ethnic Sasak suspicion. Thesis in the beginning to the Middle of The New Order, there was a sharp suspicion between ethnic groups among these three ethnic groups. This condition occurs in most elements of the West Nusa Tenggara Regional Government's bureaucracy. This condition causes the Central Government in Jakarta to worry about governance in NTB. The best choice for the central government is to recruit officials at the level of the governor, deputy governor, and other strategic officials from Jakarta. At the local level, this clarification statement is aimed at the large ethnic groups that inhabit the West Nusa Tenggara region of the islands of Lombok and Sumbawa. Thesis and antithesis when it can be proven through the reality of inter-ethnic social cohesiveness in NTB, even other ethnic groups in Indonesia. Interethnic cohesiveness is built through various social relations, such as the cross-regional and inter-ethnic distribution of state civil apparatus, local transmigration, marriage, the need to study and trade. The global era with the opening of information today, there is almost no debate about ethnic identity, and all indicators of development achievement are formulated together openly and professionally. The antithesis of the 3/I testament was answered through proof of the thesis in the synthesis of contemporary dynamics, that boundaries and ethnic identities are not important to be debated, because the common values of the nation's funds are the maintenance of social cohesiveness in the context of the Unitary Republic of Indonesia. Historical reality shows that the Unitary Republic of Indonesia is a union of many different entities. Different ethnicity, language, culture, religion, skin color, customs. Because of these differences, NKRI as a unit is needed. That unity must be maintained and maintained in accordance with the third precept of Pancasila, "Indonesian Unity."

4/I: NTB mengharap pemerataan

Keadilan sejati dan kebenaran

Agar meratalah kemakmuran

Di tanah-air ciptaan Tuhan 
4 / I: NTB hopes for equity

True justice and truth

In order for even prosperity

In God's motherland

The thesis that was built through the testament of $4 / \mathrm{I}$ am the essence of the ideals of independence as outlined in the opening of the 1945 Constitution, namely: "educating the life of the nation," one of which is welfare and justice. Likewise, the fifth precepts of Pancasila, "Social Justice for All Indonesian People." This thesis is a kind of request to the central government for equitable distribution of subsidies to the people of NTB. Testament appear in a testament in the 1970s at the Beginning of New Order rule. At that time, the economic and social conditions of the NTB community were very bad. The conditions of the 70s changed to the antithesis of the 80 s, through the status of regional food self-sufficiency. The peak of food self-sufficiency made worldwide news in 1984 when President Soeharto addressed a general assembly of the United Nations with the main topic of Gogo Rancah rice as a food source for NTB and Indonesia. An important historical record is Hamzanwadi and NTB leaders when it was an important part of the discovery and development of Gogo Rancah rice. The interesting thing about the thesis in this testament is that the deterioration in the 1970s turned into the antithesis in the form of welfare in the 1980s. If the thesis and the antithesis are combined in forming synthesis there is learning about hard work and the struggle to overcome the conditions of deterioration through scientific studies, discoveries, and trials, to development. The pinnacle of success as a synthesis in the 4/I testament is the improvement in the welfare of the people of NTB since the early 1980s.

5/I: Nahdlatul Wathan modal utama

Bagi NTB dan sasak semua

Karena lahirnya di zaman Belanda

Sebagai madrasah sumber agama

5 / I: Nahdlatul Wathan the main capital

For NTB and all of Sasak

Because of his birth in the Dutch era

As a religious source madrasah

The thesis through the testament of $5 / I$ that Nahdlatul Wathan as the first Islamic mass organization in NTB is a basic capital for regional and national development. The embryo of Nahdlatul Wathan began in 1934. It was clear that at that time, there was no name for Indonesia as a nation. The NTB region was still the Lesser Sunda region, in the occupation of the Dutch East Indies. The birth of Nahdlatul Wathan during the occupation of the Dutch East Indies clearly illustrates the atmosphere of concern with the spirit of the struggle for independence. Not all local treasures can be developed, including religious education. All can take place with the permission of the ruling government. Antithesis occurs today, that not all NTB people have comprehensive historical knowledge and information about the struggle process. Most people only know Nahdlatul Wathan as an Islamic mass organization that was born as an educational, social and propaganda instrument, without understanding the initial gait as an organization of struggle to fight for independence and give birth to Indonesia, August 17, 1945. Thesis and antithesis through the 5/I testament need to be synthesized to be a refreshed understanding of history through the process of education, outreach and dissemination. The idea must be present presence 
present presence of Indonesia and the future is a series of historical, past and future post-national the post-national era with the responsibility of educating the nation's life in accordance with the opening of the 1945 Constitution.

6/I: Perlu dijaga bersama-sama

Selaku andil utama kita

Tegakkan iman tegakkan taqwa

Di negara mereka berpancasila

6/I: Need to be taken care of together

As our main contribution

Establish faith uphold piety

In their country of success

Testament 6/I contain two important theses, namely maintaining the integrity of Indonesia Unitary the Unitary State of the Republic of Indonesia (NKRI), and a place for the establishment of faith in the frame of the state based on Pancasila. The relationship between faith-piety and the existence Unitary the Unitary Republic of Indonesia is analogous as substance and context. The substance is the upholding of faith-piety, as the manifestation of the principle of the Almighty God in the context of the Republic of Indonesia. It is impossible that faith-piety can be properly exercised and enforced if the context is not conducive to this purpose. The current condition is that there is an antithesis to the intent of this 6/I testamentary thesis in the form of a tendency to disrupt the Pancasila, and is no longer even accepted as the legal basis of the state. At the same time, there was a disruption to the context of the Unitary Republic of Indonesia in the form of separatism and unwise and unjust exploitation of natural resources. Corruption and monopolistic practices of political rights through various forms and patterns are still the color of resistance to democracy. The presence of synthesis between the thesis and the antithesis born of the 6 / I testament is needed as a form of reconstruction of thoughts and agendas to strengthen the Republic of Indonesia and the foundation of the Pancasila state. The jargon of "Indonesia has a Dead Price," is not enough in the form of narrative, but must be in the form of discursive, which gives birth to real agendas to restore awareness, understanding, and mutual recognition of the importance of Pancasila and the integrity of the Unitary Republic of Indonesia for the continuity of welfare in the Indonesian post-national era.

7/II: Aduh sayang!

Pelita NTB betambah terangnya

Karena NW lahir padanya

Berpartisipai dengan megahnya

Membela Agama Nusa dan Bangsa

7 / II: Ouch dear!

Pelita NTB has increased its light

Because NW was born to him

Participate magnificently

Defending Nusa and Nation Religion

The thesis on the 7/II testament is more comprehensive and concise with regard to the four pillars of Indonesian nationality. Line 1 refers to the presence of NTB impulsivity as part of the 
Homeland. Nahdlatul Wathan was born who in NTB automatically became a part of NKRI inclusiveness. Lines 1 and 2 indicate, as an integral part of the Unitary Republic of Indonesia, Nahdlatul Wathan has a historical responsibility in filling the entire development agenda for welfare as the opening of the 1945 Constitution. Line 4 refers to the statement of attitude that Nahdlatul Wathan testament share in the defense of religion, homeland and nation. Defending religion, which implies the responsibility of defending the religious situation in upholding the teachings of the Godhead, as is the precept of the Almighty God. Defending Nusa means the responsibility of maintaining the integrity of the Unitary Republic of Indonesia as a development context for the welfare of all the people of Indonesia as revealed by the 1945 Constitution. Defending the nation means the responsibility of maintaining the integrity of all civilizations and virtues that belong to all Indonesian children.

Regrettably, these like the testament 7/II give birth to antithesis in various forms of challenges. At the local level, not a few people forget the history of Nahdlatul Wathan's work in fighting for the establishment of religion, faith and piety, and the birth of the Indonesian nation. At the same time, the tendency to deny the results of the struggle of Nahdlatul Wathan in various advances and virtues of civilization. Nahdlatul Wathan's efforts through education, social, propaganda, and economy are considered as historical realities without historical actors. Various irrational discourses are used as a basis to deny, even reject the gait and history. The antithesis eventually gave birth to skepticism and doubt over the role of NTB as a region and historical figure. Some groups have almost denied the existence of NTB and its historical figures in the context of liberating Indonesia. Historical evidence that shows the struggle of local leaders in the era of the struggle to seize, defend, and fill independence was ignored and even rejected as a historical monument. Some of them still find it difficult to accept the jargon "a large nation is a nation that respects the services of its hero." Today's condition is the difficulty accepting their presence in the midst of being part of other people in the context of the Republic of Indonesia. Of course, this analysis must be constructed into synthesis by returning the thesis to the relativity of the post-national era through awareness, knowledge and collective action for the sake of Pancasila in the context of the Unity in Diversity of the Republic of Indonesia as stipulated in the 1945 Constitution.

\subsection{Strengthening Patterns: Hiden Curriculum, Dissemination, Socialization (Transfer, Identification, and admission of values).}

In addition to discovering thesis dialectics, antithesis, and synthesis in the testament of Hamzanwadi's work, researchers found an ideal pattern of re-strengthening the nation's character through the testament of the post-national era today. The ideal pattern was formulated through the results of a focused discussion of 43 middle school students and nine teachers. Through focused discussion, the researcher asks discussion participants to read and understand the results of this study in the form of dialectic thesis, antithesis, and synthesis of Hamzanwadi's testament. Results of a focused discussion. obtained three categories of respondent's acceptance of dialectics in Hamzanwadi's testament. First, the results of the transfer of thesis, antithesis, and synthesis information in each testament are divided into four groups, where $21 \%$ recognize the testament but do not care about its contents; $13 \%$ don't know, only heard; 26\% know the testament, realize and understand its contents, but don't yet care about their agenda for nationality; and $40 \%$ know 
the testament, realize its contents, and schedule their implementation in strengthening national values in their work and work. Second, the identification of values, related to the awareness that the thesis, antithesis, and synthesis of each need to be developed and bequeathed as local historic treasures for the nation of this post-national era.

For the value identification category, respondents are divided into three groups, namely $30 \%$ understand the meaning of a testament related to the history of past struggles; $30 \%$ understand a testament as a portrait of the state when the testament was created; and $40 \%$ of the contents of testament are related to the need to strengthen future national values. Third, the ability of admission, namely the willingness to continue to maintain, preserve, and develop all the dialectical relations in Hamzanwadi's testament as a form of responsibility for the history of nationalism in the future. In this section, the response is divided into two groups, i.e. $40 \%$ acknowledge the contents of the tetstament have become a part of him and continue to be fought for in each agenda and action; $60 \%$ recognize the contents of the testament as part of themselves, and are being fought for the next generation according to their duties (profession). The difference in responses to the contents of a testament is a necessity in the hermeneutic analysis, so that all dialectical substances must be understood as relative truths according to each reader.

All respondents $(100 \%)$ know the figure of Hamzanwadi as the creator of a testament. Hamzanwadi as Nahdlatul Wathan's founder, caregiver and mentor. According to them, what made Hamzanwadi very well known by the whole community, even in the whole country because Hamzanwadi was the first National Hero of NTB. Although $100 \%$ knew their figure, the dominant respondents knew that the initial ideals of the establishment of Nahdlatul Wathan by Hamzanwadi focused on religious education, general education, and Islamic da'wah. They do not really know the initial ideals through the testament, until now, relating to Indonesian nationality. Respondents are divided into two groups related to the responsibility of spreading national values that are born, grow and develop as illustrated in the synthesis, antithesis, and testament synthesis. The first group only realized and knew that the existence of a testament was not only an old literary work in the form of rhymes and poetry, but was full of Indonesian national agendas. The second group, know, realize that the testament contains a thesis, antithesis, and synthesis that are dialectic and all of them are related to Indonesian nationality concerning Pancasila, the 1945 Constitution, Unity in Diversity, and the Republic of Indonesia. This second group considers that the matter of national values is the responsibility of the government, so it is not so preoccupied with the national agenda through the instrument of testament.

\section{Discussion}

Based on the results of the focused discussion above, a number of things are recommended. First, the findings of the study in the form of dialectics of national values in the testament of Hamzanwadi's work must be a legacy to the nation's generation continuously. Second, all parties must take part in this important agenda according to their respective capacities. Government agencies from the lowest to the highest within certain boundaries, all the nodes in society, youth and women's organizations, and managers of educational institutions can become the main stream of this inheritance process. The issue of inheritance is felt to be somewhat disturbed given the 
dominance of development that recognizes global trends and ignores the existence of local treasures such as testament. Therefore, the value of nationality through local treasures is also ignored. This condition must be a shared responsibility in the post-national context by refreshing knowledge and formulating a joint strategy to strengthen national values derived from local treasures such as testament. The research team was asked to complete this policy document in a systematic system so that it was easily understood and implemented by the mainstream group. All respondents suggested that the results of the study in the form of dialectics of national values in this testament be distributed through primary, secondary, tertiary institutions, social institutions, and government institutions at the local level.

\section{Conclusions}

Seven testaments analyzed as a representation of the whole show the clear dialectics of the thesis, the antithesis, and the synthesis of national values. Nationality value begins with the birth of Nahdlatul Wathan as a local institution with big ideals to fight for, maintain and fill independence until the post-national era today. The next national value about dialectics is the importance of upholding faith in the context of Indonesia as a country. Do not stop there, the testament shows clearly about the dialectics of equality and fairness of the process and results of development for all Indonesian people, including in NTB. Through focused discussion, respondents realize the importance of agendas to national values as a historical legacy to future generations through the process of transfer (transfer of knowledge), identification of values (determination of attitude towards dialectics of national value), to admission (ownership of national values as individual and collective treasures as reference to actions strengthening national values). Technical agendas can be through dissemination and dissemination by all parties and all institutions in the context of the transfer, identification of values, and admission's national values in the post-national era.

\section{Reference}

Anderson, B. (1998). Imagined Communities and. In English. https://doi.org/10.1017/S0960777300000813

Darmaji, A. (2014). Dasar-Dasar Ontologis Pemahaman Hermeneutik Hans-Georg Gadamer. Refleksi, 13(4), 469-494. https://doi.org/10.15408/ref.v13i4.911

Fattah, Abdul, D. (2017). Dari NAHDLATUL WATHAN untuk INDONESIA Perjuangan TGKH. Muhammad Zainuddin Abdul Madjid (1908-1997).

Fogg, K. W. (2019). Making an Indonesian National Hero for Lombok: The shifting category of pahlawan nasional. Indonesia and the Malay World, 47(137), 1-22. https://doi.org/10.1080/13639811.2019.1560710

Hauser, A. (1985). The Sociology of Art. Alfred A. Knopf: New York.

Heryanto, A. (2019). Pasca-nasionalisme. Retrieved from arielheryanto.wordpress.com

Hun, K. Y. (1971). Nasionalisme Dan Komunitas Terbayang Dalam Karya-Karya Novel. 20, 59-70.

Kutha Ratna, N. (2009). Teori, Metode, dan Teknik Penelitian Sastra. Penerbit: Pustaka Belajar. Mennell, S. (2015). National Character, History of. In International Encyclopedia of the Social \& Behavioral Sciences: Second Edition (Second Edi, Vol. 16). https://doi.org/10.1016/B978-0-08-097086-8.03165-2 
Muladi. (2019). Wawasan Kebangsaan Prasyarat SDM Unggul. Suaramerdeka.Com, (May 2018) 2018-2021. Retrieved from https://www.suaramerdeka.com/smcetak/baca/196410/wawasan-kebangsaan-prasyaratsdm-unggul

Nahdi, K. (2013). Dinamika Pesantren Nahdlatul Wathan dalam Perspektif Pendidikan, Sosial, dan Modal. ISLAMICA: Jurnal Studi Keislaman, Vol 7(No 2). https://doi.org/10.15642/islamica.2013.7.2.381-405

Nahdi, K. (2014). Character Education and the Apreciation Nation's history (The Abandon Dialectics). 105. Yogyakarta: International Conference on Fundamental and Implementation.

Ritzer, G., \& Goodman, D. J. (2008). Teori sosiologi modern Alih Bahasa oleh Alimandan. Publisher : Jakarta: Kencana.

Rosa, M. La, Salvetti, F., Bertagni, B., \& Angeli, F. (2010). Theories and researches.

Samal, K., Dinara, Z., Tursun, G., \& Ibekeeva, S. (2014). National Mentality of Kazakhs in the Context of Ecology Culture: Tradition and Innovation. Procedia - Social and Behavioral Sciences, 114, 900-905. https://doi.org/10.1016/j.sbspro.2013.12.805

Sarmela, M. (2015). Postnationalism. The Wiley Blackwell Encyclopedia of Race, Ethnicity, and Nationalism, 1-10. https://doi.org/10.1002/9781118663202.wberen445

Sayuti, S. A. (2000). Evaluasi teks sastra: sebuah penelitian eksperimental berdasarkan teori semiotik dan estetika resepsi / Rien R. Segers; alih bahasa Suminto A. Sayuti. Yogyakarta : Adicita karya Nusa.

Ter-Minasova, S. G. (2015). In Search of National Character. Procedia - Social and Behavioral Sciences, 200 (October), 20-25. https://doi.org/10.1016/j.sbspro.2015.08.004

Tolenovna, A. K., \& Sabyrbaevna, A. Y. (2014). Problem of a Character and Circumstances in the Kazakh Prose. Procedia - Social and Behavioral Sciences, 116, 5097-5100. https://doi.org/10.1016/j.sbspro.2014.01.1080 